\title{
Preliminary Discussion on Training Mode of Innovative Talents
}

\author{
Wang Qiong \\ Harbin University, \\ Zhongxing Road No. 109, Nangang District, \\ Harbin city, China \\ Wangqiong1127@163.com
}

\author{
Chen Gang \\ Heilongjiang Institute of Science and Technology, \\ Harbin, China \\ line 4: chengang0607@163.com
}

\author{
Pan Rui \\ Harbin University, \\ Zhongxing Road No. 109, Nangang District,
}

\begin{abstract}
The cultivation of innovative talents has become a long-term and arduous task of our country and even of the world. In order to solve the problems existing in the process of the cultivation of innovative talents, beginning with the school training mode, through the optimization of curriculum system, changing teaching mode in teaching process, students' innovation ability is enhanced. Practice teaching must be strengthened, through actively developing and making full use of "practice teaching base", training students' practice by the methods of practice, engineering training, graduate design, and so on, students' practical ability and practical ability will be enhanced. At last, "double quality" teacher team construction should be paid much attention to, a team of excellent teachers will be constructed by the mode of "engineers of enterprise coming in, and compass teachers going out". The innovative talents, who have innovative thought, innovative personality and cooperative spirit, will continue to be cultivated.
\end{abstract}

Keywords- innovative talents, training mode, curriculum system, practice teaching, 'double ability' teacher

\section{INTRODUCTION}

Creative talents are needed in age of knowledge-based economy. In today's, the primary task of higher education is to provide human resources support and intellectual support for knowledge innovation and technological innovation. Higher education should be a kind of knowledge industry to develop human resources and knowledge innovation, cultivating innovative talents, this task also has become a strategic task for higher education in the world. Strengthening quality education and constructing the mode of cultivating university innovative talents, is the inevitable choice for the evolution of higher education.

In order to improve the innovation ability of colleges and universities, according to " National long-term education reform and development plan ( 2010-2020) ", " The national long-term talent development plan ( 2010-2020) "," National Twelfth Five-Year science and technology development plan " and " Excellent engineer education plan ", The construction of innovative country is promoted, with scientific development as the theme, speeding up the transformation of the mode of economic development as the order. Two key breakthroughs are needed to realize the development strategy in our country, the one is high innovation level, and the other is high entrepreneurship level. In the same professional guidance standard talents training mode of the civil engineering profession has such problems as training mode is single, lack of diversity and adaptability, as construction of deletion and weak links in practice, as the dissertation and less practice, as the insufficient attention to the students' innovative education and business training, as the improper combination of production, learn and study, and so on. The training mode of creative talents for the characteristics of Applied Undergraduate Colleges is studied to solve the problems existing in the process of the cultivation of innovative talents.

\section{OPTIMIZATION OF CURRICULUM SYSTEM}

The curriculum system refers to the labor division and cooperation between the full courses and the construction of curriculum system is also the core of the training mode, directly related to the quality of training innovative talent. Cultivation comprehensive practical ability of students should be as the breakthrough point during building curriculum system, and some courses which are good for students to master the knowledge and improve the ability of practice, should be added in the curriculum process. The college education curriculum system is mainly reflected from such proportion relationship as between the basic courses and specialized courses, theory and practice courses, compulsory courses and elective course, there are many unmatched relationship between curriculum system and the enterprise requirement model. The relationship between theory teaching and practice teaching needs appropriate treatment during construction of excellent engineer talents training mode. The practice teaching will be designed in every term. The curriculums are shown in table1. 
TABLE I. Practice TEACHING CURriculums In CiVIL ENGINEERING SPECIALTY

\begin{tabular}{|c|c|c|c|c|}
\hline time & contents & $\begin{array}{c}\text { Class } \\
\text { period }\end{array}$ & location & remarks \\
\hline \multirow{2}{*}{$\begin{array}{c}\text { entrance } \\
\text { education }\end{array}$} & $\begin{array}{l}\text { Specialty } \\
\text { education }\end{array}$ & $\begin{array}{c}8 \\
\text { classes }\end{array}$ & $\begin{array}{c}\text { On } \\
\text { campus }\end{array}$ & $\begin{array}{l}\text { school } \\
\text { teachers }\end{array}$ \\
\hline & $\begin{array}{c}\text { Engineering } \\
\text { education }\end{array}$ & $\begin{array}{c}4 \\
\text { classes }\end{array}$ & $\begin{array}{l}\text { Engineering } \\
\text { field }\end{array}$ & $\begin{array}{l}\text { Technology } \\
\text { and } \\
\text { management } \\
\text { engineers of } \\
\text { field }\end{array}$ \\
\hline \multirow{3}{*}{$\begin{array}{c}\text { The first } \\
\text { school } \\
\text { year }\end{array}$} & $\begin{array}{c}\text { Engineering } \\
\text { education }\end{array}$ & $\begin{array}{c}16 \\
\text { classes }\end{array}$ & on campus & $\begin{array}{l}\text { school } \\
\text { teachers }\end{array}$ \\
\hline & experiments & $\begin{array}{c}40 \\
\text { classes }\end{array}$ & on campus & $\begin{array}{c}\text { school } \\
\text { teachers }\end{array}$ \\
\hline & $\begin{array}{c}\text { Engineering } \\
\text { practice }\end{array}$ & 3weeks & $\begin{array}{l}\text { Engineering } \\
\text { field }\end{array}$ & $\begin{array}{c}\text { Technology } \\
\text { and } \\
\text { management } \\
\text { engineers of } \\
\text { field } \\
\end{array}$ \\
\hline \multirow{3}{*}{$\begin{array}{l}\text { The } \\
\text { second } \\
\text { school } \\
\text { year }\end{array}$} & $\begin{array}{c}\text { Engineering } \\
\text { education }\end{array}$ & $\begin{array}{c}16 \\
\text { classes }\end{array}$ & on campus & $\begin{array}{c}\text { school } \\
\text { teachers }\end{array}$ \\
\hline & experiments & $\begin{array}{c}22 \\
\text { classes }\end{array}$ & on campus & $\begin{array}{c}\text { school } \\
\text { teachers }\end{array}$ \\
\hline & $\begin{array}{c}\text { curriculum } \\
\text { design }\end{array}$ & 2 weeks & on campus & $\begin{array}{l}\text { Technology } \\
\text { and } \\
\text { management } \\
\text { engineers of } \\
\text { field, school } \\
\text { teachers }\end{array}$ \\
\hline \multirow{4}{*}{$\begin{array}{c}\text { The third } \\
\text { school } \\
\text { year }\end{array}$} & $\begin{array}{c}\text { Engineering } \\
\text { education }\end{array}$ & $\begin{array}{c}8 \\
\text { classes }\end{array}$ & on campus & $\begin{array}{l}\text { school } \\
\text { teachers }\end{array}$ \\
\hline & $\begin{array}{c}\text { curriculum } \\
\text { design }\end{array}$ & $\begin{array}{c}7.5 \\
\text { weeks }\end{array}$ & on campus & $\begin{array}{l}\text { Technology } \\
\text { and } \\
\text { management } \\
\text { engineers of } \\
\text { field, school } \\
\text { teachers }\end{array}$ \\
\hline & experiments & $\begin{array}{c}6 \\
\text { classes }\end{array}$ & on campus & $\begin{array}{c}\text { school } \\
\text { teachers }\end{array}$ \\
\hline & $\begin{array}{c}\text { specialty } \\
\text { engineering } \\
\text { practice }\end{array}$ & $\begin{array}{c}10 \\
\text { weeks }\end{array}$ & $\begin{array}{l}\text { Engineering } \\
\text { field }\end{array}$ & $\begin{array}{l}\text { Technology } \\
\text { and } \\
\text { management } \\
\text { engineers of } \\
\text { field } \\
\end{array}$ \\
\hline \multirow{3}{*}{$\begin{array}{c}\text { The forth } \\
\text { school } \\
\text { year }\end{array}$} & $\begin{array}{c}\text { Engineering } \\
\text { education }\end{array}$ & $\begin{array}{c}8 \\
\text { classes }\end{array}$ & on campus & $\begin{array}{c}\text { school } \\
\text { teachers }\end{array}$ \\
\hline & $\begin{array}{c}\text { specialty } \\
\text { engineering } \\
\text { practice }\end{array}$ & 12 weeks & $\begin{array}{l}\text { Engineering } \\
\text { field }\end{array}$ & $\begin{array}{l}\text { Technology } \\
\text { and } \\
\text { management } \\
\text { engineers of } \\
\text { field }\end{array}$ \\
\hline & $\begin{array}{l}\text { curriculum } \\
\text { design }\end{array}$ & 7 weeks & on campus & $\begin{array}{l}\text { Technology } \\
\text { and } \\
\text { management } \\
\text { engineers of } \\
\text { field, school } \\
\text { teachers }\end{array}$ \\
\hline
\end{tabular}

\begin{tabular}{|c|c|c|c|c|}
\hline & $\begin{array}{c}\text { Graduation } \\
\text { practice }\end{array}$ & 2 weeks & on campus & $\begin{array}{c}\text { Technology } \\
\text { and } \\
\text { management } \\
\text { engineers of } \\
\text { field, school } \\
\text { teachers }\end{array}$ \\
\hline
\end{tabular}

According to highlight application principles, the combination of curriculum structure and corresponding teaching contents should be updated during the design process in the undergraduate curriculum. The convert from a focus on imparting knowledge to pay more attention to the cultivation of ability and quality should be realized in the process of curriculum system. According to the local economic development and progress of science and technology needs, the teaching system should be updated, and the new knowledge, new theory and new technology should enrich the teaching content, so that curriculum and teaching contents which will meet the needs of the times will be provided for students. The reform of teaching methods should be actively promoted, and the teaching mode of "student-centered" should be established in teaching process, the role of students in classroom will be given full play to. In order to arouse students' independent thinking and innovation consciousness, the methods of heuristic teaching and research and discussion teaching should be promoted. Teaching students in accordance with their aptitude, teachers should improve students' practical and creative thinking ability. To train students to become all kinds of knowledge, skill and practice in engineering pioneer. Students should be trained to become pioneers who acquiring all kinds of knowledge, skill in engineering.

\section{OPTIMIZATION OF CURRICULUM SYSTEM}

Practical teaching resource may be developed through the establishment of practice base. Practice base is a effective way and an important guarantee for deepening students' professional knowledge, improving the students practical and innovation ability. Practice teaching base usually includes two parts: the training base in school and that out of school. Practical training base in school is generally composed of laboratory experiments and engineering practice course. Through laboratory and school practice training base, practical process of theory class can be solved, as the same time, practical ability is enhanced, and effect on the cultivation of "full potentiality, increased potential strength" innovative talents is very obvious. In order to cultivate innovative talents, higher Applied Undergraduate school should put more money and energy to the construction of laboratories and training venues of campus. Training bases out of school is established by way of the school-enterprise cooperation, and students are trained by training mode of $3+1$ or $2+1+X$, though training form of practice, engineering training and graduation design. The cooperation of production, learning and research can be promoted by School-enterprise mode. First of all, the cooperative business advice should be fully listened to, in the training program and teaching syllabus formulation process, so that the 
curriculum will be more practical application and comprehensive, and can effectively meet the market transformation needs. Secondly, teaching content in the field should be timely increased, and students should participate in the production process of construction. At the same time, a more reasonable engineering technical talents training system will be built with the method of field teaching method instructed by combination of school teachers and enterprise engineers by means of field analysis.

\section{COMPONENT OF "DOUBLE-ABILITY" TEACHER TEAM}

A multi-level and wide field professional teacher team will be built by the cooperation way, and teachers may be composed of both in school and out of school. Teachers out of school (in enterprise) will be as the part-time teachers, who have rich practical experience of the outstanding engineering, and they should generally instruct experiment, training and practice guidance to improve experiment and practice instruction level. In order to improve practical skills of teachers in school, the professional teachers should regularly exchange to enterprises to rich practical experience. Professional teachers should be encouraged to participate in professional skills training. Professional knowledge of teachers in school should be constantly updated by means of organizing them to visit study and understand the trends of professional development in the training base. Young teachers should be encouraged to related enterprise as a parttime job, without affecting the normal teaching conditions.

\section{CONCLUSION}

The cultivation of innovative talents is a kind of new talent cultivation mode, at the same time, it also is a complex system engineering. The innovative talents, who can adapt to the requirements and development of the times, will be really cultivated only by means of the continuous exploration, practice, and constantly improve.
The students' knowledge and potential will be activated, and the innovative talents, who have innovative thought, innovative personality and cooperative spirit, will continue to be cultivated. Promotion of "innovative talents training mode" is a long-term process it must be closely combined with the situation of our country. The favorable opportunity should be seized, and the training mode and systems must be improved. Laboratory and training base construction should be actively promoted. Combination of production, learn and research should be further promoted by means of school-enterprise cooperation mode. All kinds of resources in school and out of school should be made full use of in order to service for painting the "innovative talents".

\section{ACKNOWLEDGMENT}

This research was supported by Mode and evaluation system of innovative talents cultivation in civil engineering specialty of application type from education department of Heilongjiang province, Grants No. JG2012010399.

\section{REFERENCES}

[1] Liu Tian-E. Study on the Training Mode of Innovative Talents in Universities[J].Journal of Chongqing City Management Vocational College, Mar. 2008 Vo.l 8.

[2] Liu Rong-gui, Cai Dong-sheng. Compound Talent Training Mode for Civil Engineering Specialty[J]. Journal of Architectural Education in Institutions of Higher Learning, Vol. 21 No. 2, 2012.

[3] Yi Yuan-Xiang. Reform and practice of the system of training innovative talent[J]. Higher Education of Sciences,2008.

[4] XU Cheng-xiang, ZENG Lei, LIU Chang-ming. Practice of engineering-learning alternating cooperation training modein civil engineering education $[\mathrm{J}]$. Journal of Architectural Education in Institutions of Higher Learning, Vol.20 No.5 ,2011.9.

[5] Liu Hong-wei, Feng Lei. Research on the Quality Monitoring and Evaluation Systam for the School enterprise Cooperation Talent Training Mode[J]. Electronic Sci.\& Tech. /.Tun. 15. 2010. 